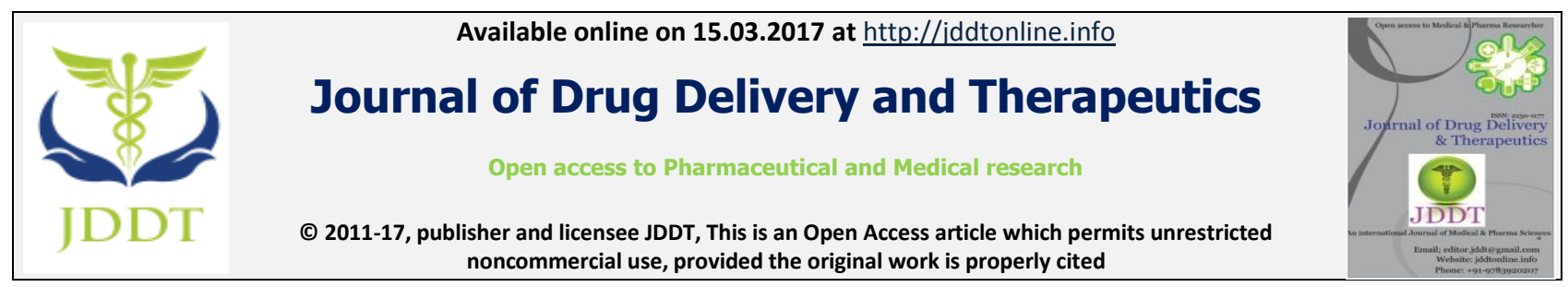

Research Article

\title{
ANTIULCER ACTIVITY OF AMARANTHUS SPINOSUS LEAF EXTRACT AND ITS COMPARISION WITH FAMOTIDINE IN SHAY RATS
}

\author{
Panda Santosh Kumar', Sarkar Gourab ${ }^{2}$, Acharjya Manini ${ }^{2}$, Panda P.K ${ }^{2}$ \\ ${ }^{1}$ Professor and Head (Pharm.D), Avanti college of pharmacy, Hyderabad, India \\ ${ }^{2}$ UDPS, Utkal University, Bhubaneswar, India
}

\section{ABSTRACT}

Anti-ulcer activities of petroleum ether, chloroform, Ethanolic extract of Amaranthus spinosus leaf were tested for anti-gastric ulcer activity in Shay rat model. Oral dose of $400 \mathrm{mg} / \mathrm{kg}$ of ethanolic extract reduced the ulceration and with $800 \mathrm{mg} / \mathrm{kg}$ body weight ethanolic extract there is the complete absence of ulceration. The anti-gastric activity of ethanolic extract of A.spinosus $800 \mathrm{mg} / \mathrm{kg}$ body weight was found to be equal to the effect produced by $2 \mathrm{mg} / \mathrm{kg}$ of Famotidine orally. The reduction in gastric activity was more with Famotidine and the reduction in peptic activity is more with ethanolic extract of A.spinosus. All extracts are safe up to $4000 \mathrm{mg} / \mathrm{kg}$. The result of petroleum ether, chloroform and aqueous extract in respect of anti-ulcer activity are less prominent.

Key words: Amaranthus spinosus, Shay rat model, Famotidine, Peptic activity

Article Info

Received Jan 30, 2017; Review Completed Feb 27, 2017; Accepted March 15, 2017; Available online March 15, 2017

Cite this article as:

Panda SK, Sarkar G, Acharjya M, Panda PK, Antiulcer activity of amaranthus spinosus leaf extract and its comparision with famotidine in shay rats, Journal of Drug Delivery and Therapeutics. 2017; 7(2):96-98. DOI: http://dx.doi.org/10.22270/jddt.v7i2.1392

*Address for Correspondence

Santosh Kumar Panda, Professor and Head (Pharm.D), Avanti college of pharmacy, Hyderabad, India, Email: santoshsf1@gmail.com

\section{INTRODUCTION}

Famotidine is found to be useful in healing gastric ulcer and are used in the treatment of gastric ulcer and duodenal ulcer 1. According to Ayurveda ulcer formation occurs due to improper digestion of food, excess of stress, excess secretion of $\mathrm{HCl}^{2}$. It is experimentally found that Famotidine $2 \mathrm{mg} / \mathrm{kg}$ body weight has shown to complete cure of ulcer and reduces the peptic activity. Aerial parts of Amaranthus spinosus extract are widely used by tribal's of south Odisha to heal peptic ulcer and relief from stomach pain without precipitating any side effects but there is no scientific proof to prove this in literature. The present research was conducted to evaluate anti-ulcer activity of aerial parts of Amaranthus spinosus extract to establish a scientific proof against such traditional utility compared with Famotidine in Shay rat model.

\section{MATERIALS AND METHODS:}

Amaranthus spinosus leaf as test plant, Famotidine used as standard drug. The other reagents used were Topfer's reagent, $0.01 \mathrm{~N}$ Sodium hydroxide, Tyrosine, Folin's phenol reagent, 1\% Carboxy methoxy cellulose, phenolphthalein indicator etc.

Studies in Shay rat ${ }^{3}$

Albino rats of either sex were taken weighing around $150-200 \mathrm{gm}$. Rats weighing $150 \mathrm{gm}$ or above were fasted for $72 \mathrm{hr}$ and below the weight of $150 \mathrm{gm}$ were fasted for $48 \mathrm{hr}$. the rats were allowed to take water ad libitum 
Under ether anaesthesia The pylorus ligation was made. Different doses of drugs (Famotidine) were administered to groups containing six rats each. Soon after recovery from anaesthesia the animals are kept in separate cages and care was taken to avoid coprophagy. Control group was treated with $1 \% \mathrm{CMC}$ and kept for $24 \mathrm{hrs}$ without food and water after pyloric ligation. The animals were sacrificed after $24 \mathrm{hrs}$ by means of spinal traction. The rat was kept on its back, the viscera was opened. The oesophagus end of the stomach was also ligated and then stomach was isolated by dissecting it beyond pyloric ligation. Then the stomach was cut open through its greater curvature and the contents were drained into a $50 \mathrm{ml}$ beaker and the stomach mucosa was washed with $1 \mathrm{ml}$ of distilled water. Into this beaker containing gastric juice $(1 \mathrm{ml}), 9 \mathrm{ml}$ distilled water was added and then the contents were centrifuged for $10 \mathrm{~min}$ at $2000 \mathrm{rpm}$. Then the volume of the supernatant layer was measured. From these supernatant layer aliquots were taken for the determination of free acidity, total acidity and peptic acidity. The gastric mucosa was examined for ulcers by magnifying lenses.

Table 1: Effect of various extracts of Amaranthus spinosus in pyloric ligated ulcer model in rat (VGJ: Volume of gastric juice, TA: Total Acidity, FA: Free acidity, PA: Peptic activity)

\begin{tabular}{|c|c|c|c|c|c|c|}
\hline Group & Treatment & $\begin{array}{c}\text { VGJ } \\
(\mathbf{m l} / \mathbf{1 0 0 g m})\end{array}$ & $\begin{array}{c}\text { FA } \\
(\mathbf{m g} / \mathbf{1 0 0 g m})\end{array}$ & $\begin{array}{c}\text { TA } \\
(\mathbf{m g} / \mathbf{1 0 0 g m})\end{array}$ & $\begin{array}{c}\text { PA } \\
\boldsymbol{\mu m o l T y r o s i n e} / \mathbf{1 0 0 g m}\end{array}$ & $\begin{array}{c}\text { Ulcer } \\
\text { Index }\end{array}$ \\
\hline I & Vehicle control & $5.22 \pm 0.01014$ & $2.7 \pm 0.0601^{\mathrm{a}}$ & $12.4 \pm 0.0557^{\mathrm{a}}$ & $2277.85 \pm 57.72^{\mathrm{c}}$ & 5 \\
\hline II & PEAS 400mg/kg & $4.32 \pm 0.654^{\mathrm{a}}$ & $1.43 \pm 0.06^{\mathrm{b}}$ & $2.8 \pm 0.042^{\mathrm{b}}$ & $1576.03 \pm 0.049^{\mathrm{c}}$ & 3 \\
\hline III & PEAS 800mg/kg & $3.66 \pm 0.049^{\mathrm{b}}$ & $1.47 \pm 0.049^{\mathrm{a}}$ & $3.07 \pm 0.065^{\mathrm{a}}$ & $1568.73 \pm 0.461^{\mathrm{c}}$ & 3 \\
\hline IV & CEAS 400mg/kg & $4.4 \pm 0.057^{\mathrm{a}}$ & $1.8 \pm 0.057^{\mathrm{b}}$ & $3.2 \pm 0.057^{\mathrm{b}}$ & $1593.63 \pm 1.236^{\mathrm{c}}$ & 3 \\
\hline V & CEAS 800mg/kg & $4.4 \pm 0.06^{\mathrm{a}}$ & $1.51 \pm 0.04^{\mathrm{b}}$ & $2.63 \pm 0.049^{\mathrm{b}}$ & $1575.62 \pm 1.001^{\mathrm{c}}$ & 3 \\
\hline VI & EEAS 400mg/kg & $4.15 \pm 0.042^{\mathrm{a}}$ & $0.88 \pm 0.06^{\mathrm{b}}$ & $1.8 \pm 0.057^{\mathrm{b}}$ & $1406.65 \pm 1.148^{\mathrm{c}}$ & 1 \\
\hline VII & EEAS800mg/kg & $3.37 \pm 0.042^{\mathrm{a}}$ & $1.0 \pm 0.062^{\mathrm{a}}$ & $1.48 \pm 0.047^{\mathrm{b}}$ & $1336.9 \pm 1.473^{\mathrm{c}}$ & 0 \\
\hline VIII & Famotidine & $1.7 \pm 0.036^{\mathrm{a}}$ & $1.0 \pm 0.051^{\mathrm{a}}$ & $1.35 \pm 0.061^{\mathrm{a}}$ & $1378.55 \pm 0.96^{\mathrm{c}}$ & 0 \\
\hline
\end{tabular}

Results are expressed mean \pm SEM of six readings; Significance evaluated by one way analysis of variance(ANOVA) followed by dunnett's t-test versus control group

${ }^{\mathrm{a}} \mathrm{P}<0.001,{ }^{\mathrm{b}} \mathrm{P}<0.005,{ }^{\mathrm{c}} \mathbf{P}<0.05,(\mathrm{n}=6)$

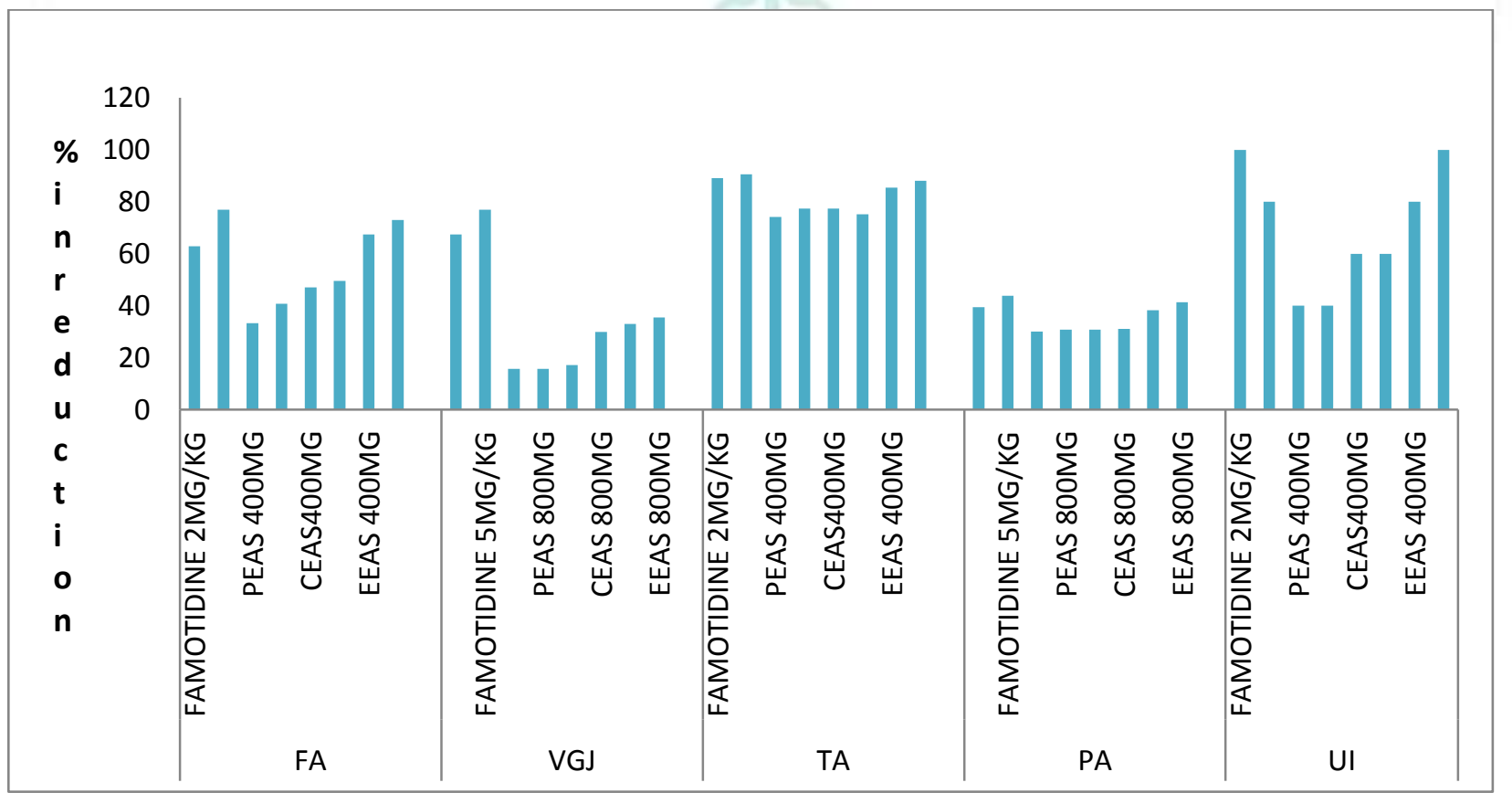

PEAS- Petroleum ether extracts of Amaranthus spinosus CEAS- Chloroform extract of Amaranthus spinosus EEAS- Ethanolic extract of Amaranthus spinosus

Figure 1: Graph showing effect of various extracts of A.spinosus on pyloric ligation ulcer model in rats \% reduction of VGJ, TA, PA, FA, UI. 


\section{Total Acidity (TA)}

A volume of $5 \mathrm{ml}$ diluted gastric juice was titrated with $0.01 \mathrm{~N}$ Sodium hydroxide run from a micro burette using phenolphthalein as an indicator and the acidity was expressed as $\mathrm{mg} \mathrm{HCl} / 100 \mathrm{gm}$ body weight of rat.

\section{Free acidity (FA)}

It is determined by using Topfer's reagent as an indicator and titrating with sodium hydroxide $(0.01 \mathrm{~N})$ which was run until canary colour was observed. The free acidity was expressed as $\mathrm{mg} / 100 \mathrm{gm}$ body weight.

\section{Peptic activity (PA)}

The method as followed by the Lowry et al 1951 was followed to estimate peptic activity and was expressed as $\mu$ mol Tyrosine/100gm body weight ${ }^{4}$.

\section{Ulcer Index (UI)}

The method of Anderson and soman (1965) was followed for scoring the ulcer index.

\section{RESULT AND DISCUSSION}

Results are interpreted in table and figure. Famotidine significantly reduces the total acidity, free acidity, peptic activity and ulcer index by $90.56 \%, 70.37 \%, 43.79 \%$, and $100 \%$ respectively at a concentration of $2 \mathrm{mg} / \mathrm{kg}$. In case of preliminary study with $200 \mathrm{mg} / \mathrm{kg}, 400 \mathrm{mg} / \mathrm{kg}$, $800 \mathrm{mg} / \mathrm{kg}$ of petroleum ether, chloroform and aqueous extracts of leaves of Amaranthus spinosus didn't show any remarkable inhibition of free acidity, total acidity, peptic activity, volume of gastric juice and ulcer index. The ethanolic extract at a dose of $800 \mathrm{mg} / \mathrm{kg}$ body weight reduces the volume of gastric juice, free acidity, total acidity, peptic activity and ulcer index. Ulceration was inhibited by $60 \%, 80 \%, 100 \%$ in the concentration $200,400,800 \mathrm{mg} / \mathrm{kg}$ respectively. Similarly percentage of inhibition of volume of gastric juice was estimated

\section{REFERENCES}

1. Douglas W.W., Histamine and 5-hydroxy tryptamine and their antagonistic in Goodman and Gillman's. The pharmacological basics of Therapeutics, $7^{\text {th }}$ ed. MacMillam publishing company 1985.

2. Gupta M, Mazumder UK., Manikandan L., Bhattacharya S., Senthi Kumar GP, Suresh R., Antiulcer activity of ethanol extract of Terminalia Brandis in Swiss albino rats. J Ethnopharmacol; 2005; 97:405-8

3. Shay H, Komarosa Fels SS, Meranze D.Development of Gastric ulcer by Pyloric ligation technique. Gastroenterology. $1945 ; 5: 43-61$.
$25.67 \%, 32.94 \%, 35.44 \%$ respectively. Free acidity was reduced by $54.44 \%, 67.4 \%, 72.96 \%$ respectively. Likewise, total acidity $86.04 \%, 85.48 \%, 88.06 \%$ and peptic activity $34.4 \%, 38.24 \%, 41.3 \%$ reduces in concentration of $200,400,800 \mathrm{mg} / \mathrm{kg}$ body weight respectively. On the basis of observation it was confirmed that the active principle present in ethanolic extract of Amaranthus spinosus is responsible for reducing total acidity, free acidity, volume of gastric juice, peptic activity, ulcer index. As ethanolic extract of reduces the ulceration as compared to Famotidine. So, it may be inferred that there is reduction in $\mathrm{HCl}$ secretion as conformed by reducing acidity $(\mathrm{p}<0.05)$ and peptic activity $(\mathrm{p}<0.01)$. The active constituents present in $800 \mathrm{mg} / \mathrm{kg}$ of ethanolic extract of Amaranthus spinosus completely inhibited the ulceration and gives protection as given by $2 \mathrm{mg} / \mathrm{kg}$ body weight of Famotidine in Shay rat.

\section{CONCLUSION}

The ethanolic extract of Amaranthus spinosus completely inhibited the ulceration in Shay rat model as compared to results of Famotidine $2 \mathrm{mg} / \mathrm{kg}$. So, it may be inferred that inhibition of ulceration and acidity is may be due to reduced $\mathrm{HCl}$ secretion that is reducing acidity $(\mathrm{p}<0.05)$ and peptic activity $(\mathrm{p}<0.01)$.

\section{Acknowledgement:}

I take opportunity to express my deep sense of gratitude to Prof P.K Panda, Former Director and Head UDPS, Utkal University, Bhubaneswar for suggesting the topic and for his inspiring guidance as well as encouragement throughout the progress of the study. I acknowledge my deep thanks to my parents, sister and my dear friend and for giving me time and helping me to carry out this project and without them I can't make it possible.

4. Lowry O.H, Roserbrough, NJ, Farr AL and Randall RJ, Protein measurement with Folin-Phenol reagent, J.Bio Chem. $1951 ; 19(23): 265-267$.

5. Anderson, Hand Soman, P3B, Role of Histamine in gastric ulceration in guinea pig. Some observations on a new method, J. Pharm. Pharmacol. 1965:92-97.

6. Panda PK, Panda DP, The causes and mechanism of formation of peptic ulcer, Pharmatimes 1992; 24(7):15-16. 